\title{
PHYSICAL ACTIVITY, PHYSICAL DEVELOPMENT AND EATING HABITS WITHIN THE LIFESTYLE OF STUDENTS FROM UKRAINE
}

\author{
Anatolii Tsos $^{1,2}$, Barbara Bergier ${ }^{1}$, Józef Bergier ${ }^{1}$
}

\author{
${ }^{1}$ Pope John Paul II State School of Higher Education in Biala Podlaska \\ ${ }^{2}$ Lesya Ukrainka Eastern European National University
}

Tsos A., Bergier B., Bergier J. (2014), Physical activity, physical development and eating habits within the lifestyle of students from Ukraine. Health Problems of Civilization, 4 (8), p. 46-53

\begin{abstract}
Summary: The aim of this study was to investigate the physical activity, the basic parameters of physical development, and eating habits of students from Ukraine. The research method of diagnostic survey using a IPAQ questionnaire and nutrition questionnaire was carried out in 2013 among 2125 students, for $60.8 \%$ of women and $39.2 \%$ men.

As a result of studies beneficial indicators of total physical activity were demonstrated, with higher physical activity of persons who have sufficient amount of free time.

The level of BMI indicator is in the majority of students at a normal level. The amount and frequency of meals is a sign of positive healthy behaviors.

Also the disadvantageous behaviors occur, such as avoidance and loss of control over eating and induction of vomiting for the sake of one's body.
\end{abstract}

Keywords: physical activity, physical development, eating habits, students from Ukraine

\section{Introduction}

It is quite commonly emphasized that regular physical activity is an important factor in a healthy preventive lifestyle (Blair, Brodney 1999, Andersen et al. 2006, Blair et al. 2001). In order to familiarize oneself with the status and determinants of physical activity levels of students active research has been conducted in recent years in Poland (Biernat 2011, Bergier, Kapka - Skrzypczak et al. 2012 Mynarski, Rozpara, Królikowska et al. 2012). It is estimated that the proper physical activity of the youth puts restrains to a large extent on the contemporary problem of civilization which is overweight and, consequently, obesity.

It is almost universally accepted that obesity is the cause of numerous diseases, including mainly cardiovascular system and thereby a factor which lowers the quality of life. Obesity consequently facilitates the development of other diseases. Over the past few years there has been a disturbing trend of growing number of the overweight people. According to the World Health Organization in 2007 a number of overweight people in the world amounted to 1,5 billion and 523 million of those obese, and already in 2015 these numbers will amount to 1,6 billion and 700 million people ${ }^{1}$. Also Polish studies indicate problems of overweight and obesity within the society (Rywik et al., 2003, Szponar et al., 2003, Zdrojewski et al. 2004). This problem also applies to Polish university students (Rębacz - Maron et al. 2013, Romanowska - Tołłoczko 2011, Szczodrowska - Krysiak 2013, Myszkowska-Ryciak i in. 2011, Seń i in. 2012, Marzec - Koch 2013, Krejpcio i in. 2013). The results of scientific research on the state of nutrition of students in our country are not unequivocal. Surveys among female students from the University of Szczecin (Rębacz- Maron et al. 2013) showed a positive image of the self-assessment of their physical activity and nutritional status in the light of BMI factor. Assessment of daily portions of food rations among the students of the Medical University of Lublin showed very low energy values in both women and men. A new phenomenon is reaching for dietary supplements. Survey among students of Dietetics of the University of Life Sciences in Poznan and psychology Academy of Special Education in Warsaw have shown that it is common among students, and one of the reasons is aesthetics (Krejpcio i in. 2013). These results of research (conducted in recent years), on the diet habits of students indicate that the problem is still present.

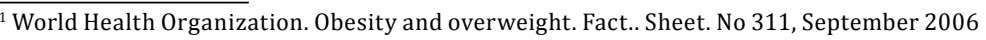

Address for correspondence: Józef Bergier, Pope John Paul II State School of Higher Education in Biala Podlaska, Sidorska 95/97, 21-500 Biała Podlaska, e-mail: j.bergier@pswbp.pl, phone: (83) 3449900

Tables: 6 Figures: 4 References: 17 Full-text PDF www.hpc.edu.pl Copyright (C) Pope John Paul II State School of Higher Education in Biała Podlaska, Sidorska 95/97, 21-500 Biała Podlaska Indexation: Index Copernicus, Database AGRO, ProQuest, Polish Ministry of Science and Higher Education. This is an open-access article distributed under the terms of the Creative Common Attribution Non-commercial license (http://creativecommons.org/ licenses/by-nc/3.0), which permits use, distribution and reproduction in any medium, provided the original works is properly cited, the use is noncommercial and is otherwise in compliance with the license. 


\section{Research methodology}

Aim of the study. The aim of the study was to investigate the level of physical activity, physical development, the basic parameters including body mass index (BMI), and eating habits as well as behaviors related to the above among students from Ukraine.

\section{Material and research methods}

The study was conducted in 2013 among 2,125 students from 12 faculties at the National University in Lutsk in Ukraine in the age range between 17-22, including 1,291 women (60,8\%) and 834 men $(39,2 \%)$.

For the evaluation of physical activity a long version of the International Physical Activity Questionnaire (IPAQ) supplemented by the author's questionnaire was applied. Data on basic parameters of physical development which enabled the calculation of BMI was also applied. A questionnaire regarding eating habits was applied, in which questions from the research conducted at the Institute of Medicine in Lublin were used.

\section{Research results}

\section{Characteristics of physical activity and physical development.}

The respondents indicated in the majority $(51,4 \%)$ for too little free time, and the sufficient amount of time was indicated by $37.7 \%$. Level of physical activity is satisfactory, since $50,2 \%$ has high activity and only $5,2 \%$ has a low one. Self-assessment of physical fitness is assessed by a vast majority as the average $-70,6 \%$ with high efficiency at the level of $13,9 \%$.

What is also positive is the image of their sport activity, since 7 or more disciplines are trained by $23,1 \%$ and $36,3 \%$ of them train 4-6 disciplines. Only 3,1\% of the students expressed the opinion that they do not practice any sport. Dreams of practicing disciplines are less impressive, as a clear majority $(69,6 \%)$ lists from one to two disciplines, and only $13,0 \%$ indicated three or more.

The characteristics of the physical development involves positive development of BMI factor, which in case of $74,2 \%$ places their body weight at a normal level, with only $8,7 \%$ of people who are overweight. Slightly more critical self-assessment of their physique, as $69,2 \%$ rated it as normal, but $13,0 \%$ noted the overweight. Almost similar percentage distribution of student youth from Ukraine wants to lose weight $-47,8 \%$, and does not see the need for it $-52,2 \%$.

The vast majority of respondents $(70,7 \%)$, for the sake of their figure, would not want to gain weight, while $29,3 \%$ of students expressed disagreement with this (Table 1 ).

Table 1. Researched students according to individual features

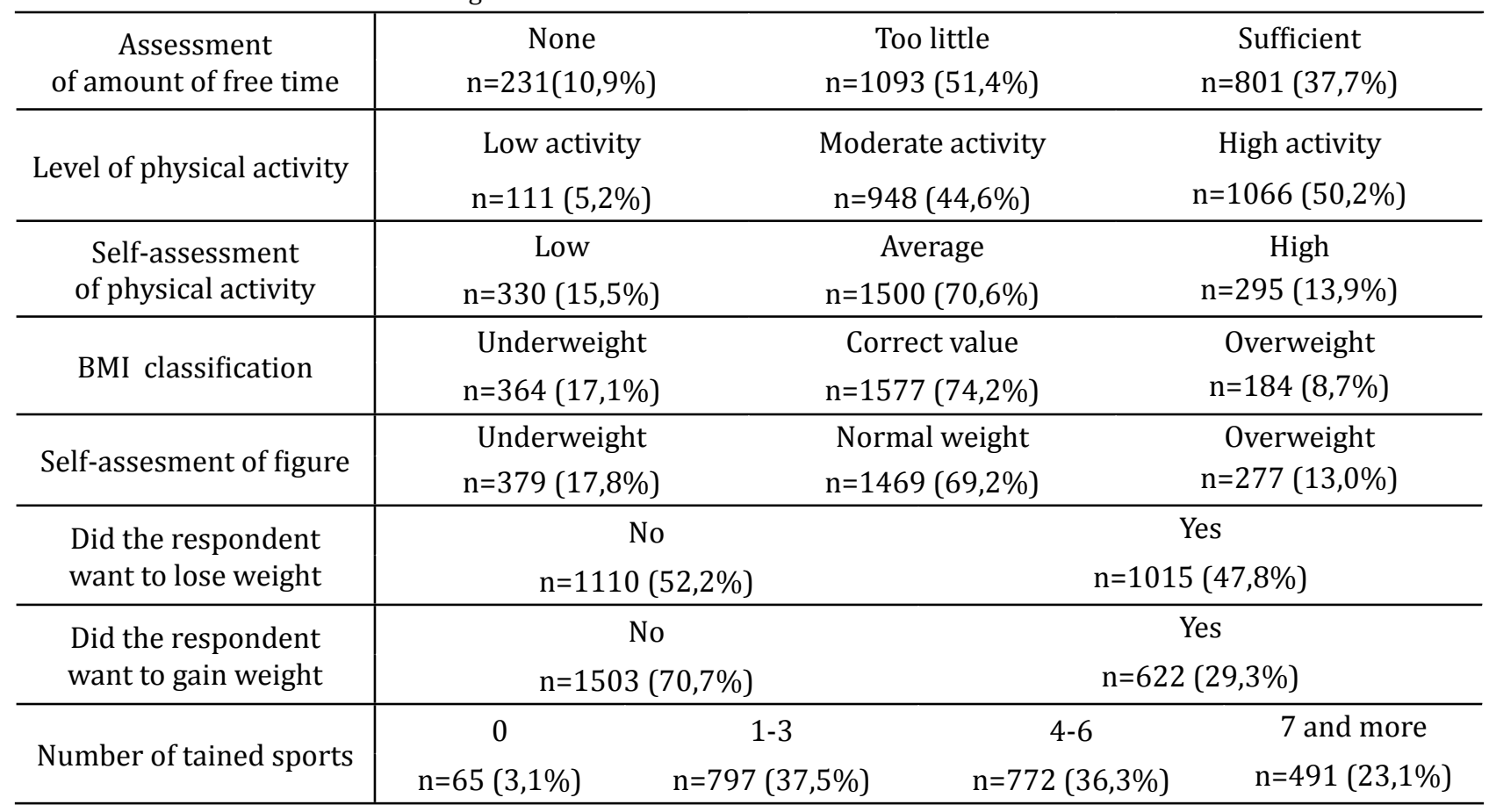




\begin{tabular}{|c|c|c|c|c|c|}
\hline \multirow{2}{*}{$\begin{array}{c}\text { Number of sport } \\
\text { types the respondents } \\
\text { wishes to train }\end{array}$} & \multicolumn{2}{|c|}{$\begin{array}{c}0 \\
n=383(18,0 \%)\end{array}$} & \multirow{2}{*}{$\begin{array}{c}1-2 \\
n=1466(69,0 \%) \\
\text { High } \\
n=1185(55,9 \%)\end{array}$} & \multicolumn{2}{|c|}{$\begin{array}{c}3 \text { and more } \\
n=276(13,0 \%)\end{array}$} \\
\hline & $\begin{array}{c}\text { Low } \\
n=24(1,1 \%)\end{array}$ & $\begin{array}{c}\text { Average } \\
\mathrm{n}=443(20,8 \%)\end{array}$ & & $\begin{array}{c}\text { Very high } \\
n=370(17,4 \%)\end{array}$ & $\begin{array}{c}\text { Perfect } \\
\mathrm{n}=103(4,8 \%)\end{array}$ \\
\hline
\end{tabular}

\section{Factors which condition physical activity of students}

The overall level of physical activity of young people studying in Ukraine is 3,560 MET / min / week * and in comparison with other studies it is high. A positive development is also the fact of large activity level in sports 1,124 MET (Fig. 1).

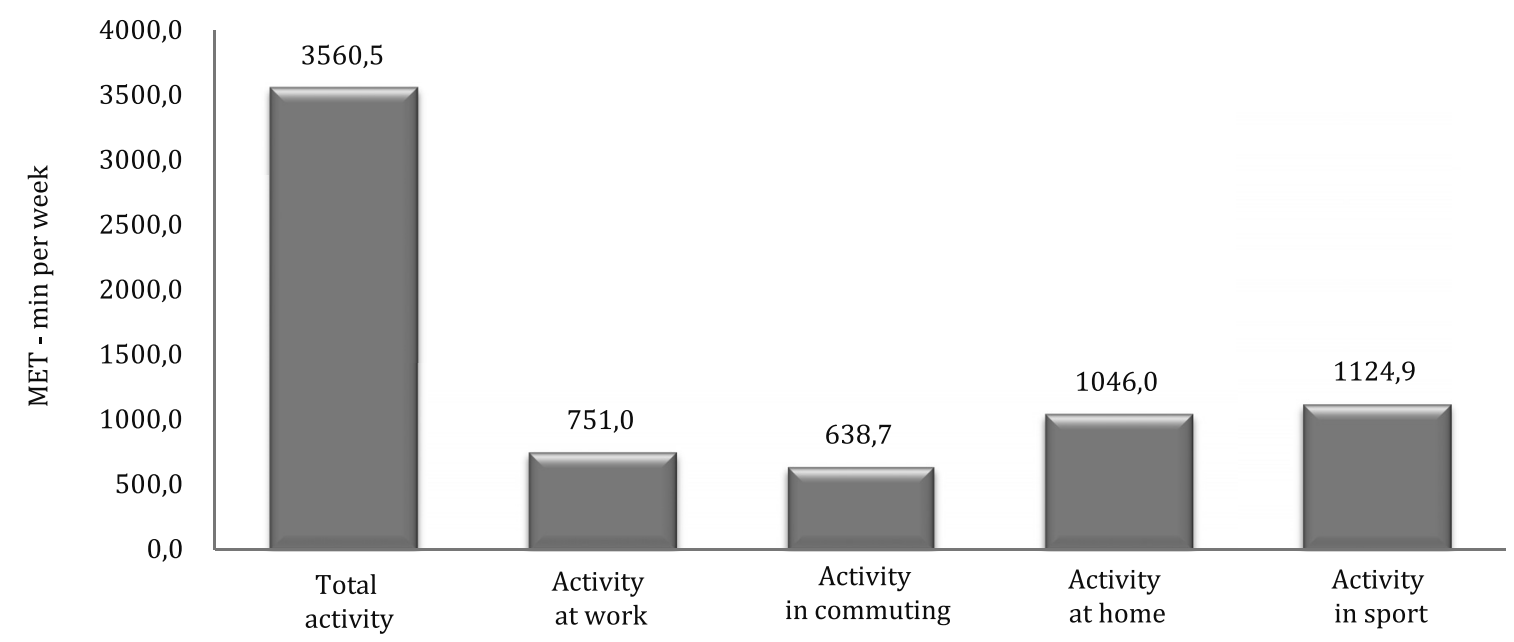

Figure 1. Areas of physical activity of students

Amount of free time students significantly determines their level of total physical activity. The lowest level of activity is characteristic of a group that does not have the free time - 3,280 MET.

It should be emphasized that in sports activities significantly higher scores were achieved by students

with sufficient free time- 1,195 MET, with values of too short a time- 1,130 MET, and who do not have free time solely 823 MET (Fig. 2), (Table 2).

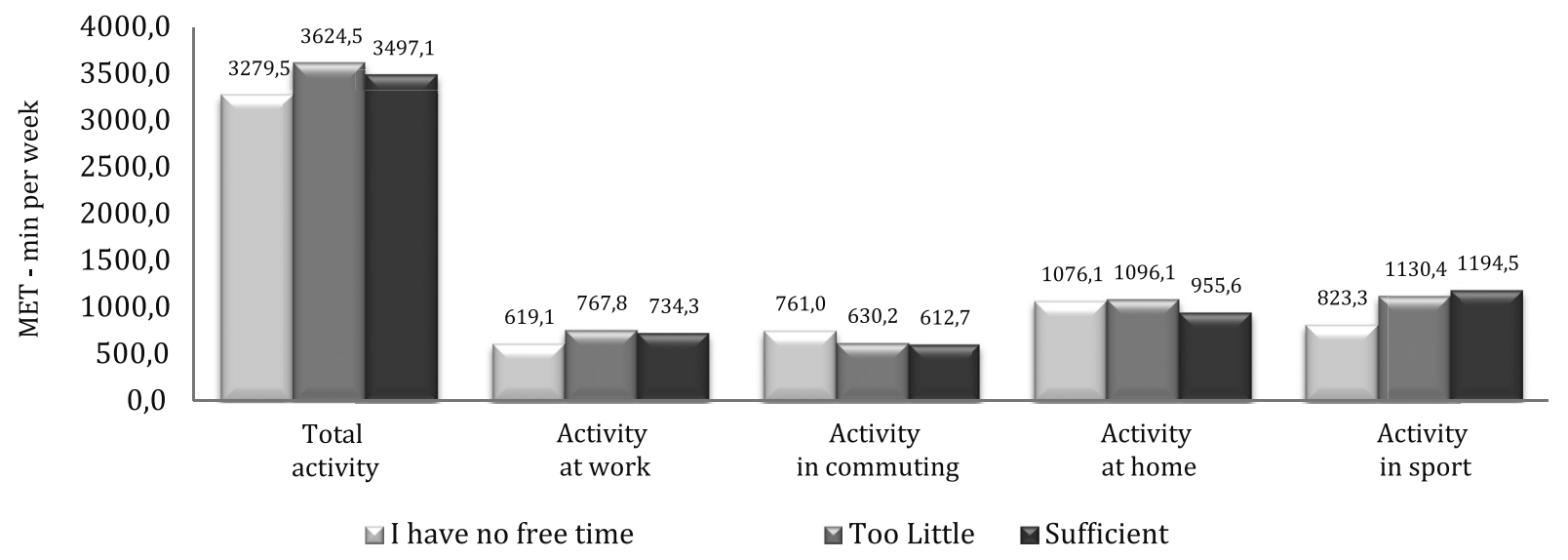

Figure 2. Areas of physical activity of students including their free time 
Table 2. Diversification of areas of physical activity of students including the amount of free time

\begin{tabular}{|l|c|c|c|}
\hline \multicolumn{4}{|c|}{ Kruskal-Wallis Test } \\
\hline \multicolumn{1}{|c|}{ Area of activity } & $\mathrm{H}$ & $\mathrm{p}$ & Differences \\
\hline Total activity & $\mathbf{6 , 7 4 8 2 5 1}$ & $\mathbf{0 , 0 3 4 2} *$ & $\mathbf{1 - 2}$ \\
\hline Activity at work & $\mathbf{8 , 5 8 4 0 6 7}$ & $\mathbf{0 , 0 1 3 7}$ & $\mathbf{1 - 2 , 3}$ \\
\hline Activity in commuting & $\mathbf{6 , 1 1 9 2 5 9}$ & $\mathbf{0 , 0 4 6 9}$ & $\mathbf{1 - 3}$ \\
\hline Activity at home & $\mathbf{1 5 , 6 8 3 0 5}$ & $\mathbf{0 , 0 0 0 4}$ & $\mathbf{2 - 3}$ \\
\hline Activity in sport & 32,49209 & $<\mathbf{0 , 0 0 0 1}^{*}$ & $\mathbf{1 - 2 , 3}$ \\
\hline
\end{tabular}

*- Significant diversification at $\mathrm{p}<0,05$

Higher self-assessment of fitness highly correlates with the size of the total activity and its particular areas.

In case of self-assessment of fitness defined as high, physical activity is at the level of 4,410 MET and that defined as the average - 3,560MET and as a low one only 2,669 MET. Also in the area of physical activity at work and in there occur significantly higher rates which are defined for students with high self-assessment of their physical fitness (Fig. 3), (Tab. 3).

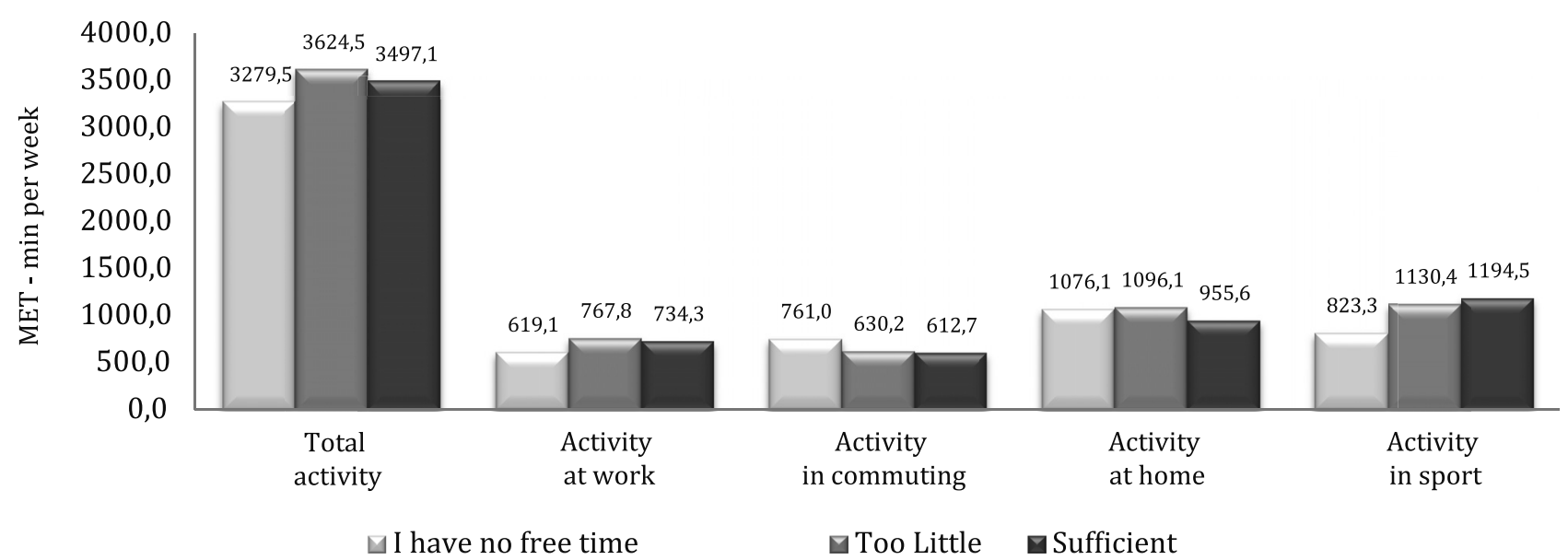

Figure 3. Areas of physical activity of students including self-assessment of physical activity

Table 3. Diversification of areas of physical activity of students in the scope of self-assessment of physical activity

\begin{tabular}{|l|c|c|c|}
\hline \multicolumn{4}{|c|}{ Kruskal-Wallis Test } \\
\hline \multicolumn{1}{|c|}{ Area of activity } & $\mathrm{H}$ & $\mathrm{p}$ & Differences \\
\hline Total activity & $\mathbf{8 3 , 8 5 4 4 5}$ & $<\mathbf{0 , 0 0 0 1} *$ & $\mathbf{1 - 2 , 3 ; 2 - 3}$ \\
\hline Activity at work & $\mathbf{5 2 , 9 3 3 9 1}$ & $<\mathbf{0 , 0 0 0 1} *$ & $\mathbf{1 - 2 , 3 ; 2 - 3}$ \\
\hline Activity in commuting & 0,2476279 & 0,8835 & - \\
\hline Activity at home & 4,439918 & 0,1086 & - \\
\hline Activity in sport & $\mathbf{1 4 3 , 2 4 1 7}$ & $<\mathbf{0 , 0 0 0 1} *$ & $\mathbf{1 - 2 , 3 ; 2 - 3}$ \\
\hline
\end{tabular}

*- Significant diversification at $\mathrm{p}<0,05$

\section{Student nutrition patterns versus physical activity}

The pattern in terms of amounts and frequency of meals reveals the fact that nearly half of the students eats 3 meals a day $-47,0 \%$, with a similar percentage eating 1-2 meals - (24,5\%), and 4 and more (28,5\%). Breakfast is the most widely consumed meal every day $(39,8 \%)$, or several times a week $-28,4 \%$. What is an unfavorable phenomenon is the fact that as many as $31,8 \%$ of respondents do not eat breakfast at all. In case of the second breakfast consumption the answer which dominates - $(44,6 \%)$ and a few times a week. The frequency of eating

* In the following paragraphs the form of the abbreviation 'MET' will be used 
lunch every day is the highest of all meals and equates to - 79,0\%, while for $19,9 \%$ it is several times a week, and only a non-material number of respondents admitted to not eating this meal - 1.1\%. Afternoon snack is consumed by nearly half of the respondents - $46.5 \%$ several times a week. Supper is eaten every day by the vast majority of them; daily- (73,9\%), and a few times a week - (20,7\%) (Tab. 4).

Table 4. Volume and frequency of consumption of meals by the respondents

\begin{tabular}{|c|c|c|c|c|}
\hline \multicolumn{5}{|c|}{ Daily number of meals } \\
\hline Gender & $1-2$ & 3 & 4 and more & Statistics \\
\hline Female & $351(29,9 \%)$ & $550(46,9 \%)$ & $272(23,2 \%)$ & \multirow{3}{*}{$\begin{array}{c}X^{2}=64,78 \\
p<0,0001^{*}\end{array}$} \\
\hline Male & $124(16,2 \%)$ & $362(47,3 \%)$ & $280(36,6 \%$ & \\
\hline Total & $475(24,5 \%)$ & $912(47,0 \%)$ & $552(28,5 \%)$ & \\
\hline
\end{tabular}

Frequency of eating breakfast

\begin{tabular}{l|ccc|c}
\multicolumn{1}{c|}{ Gender } & Every day & Several times a week & Don't eat & Statistics \\
\hline Female & $427(39,8 \%)$ & $276(25,7 \%)$ & $370(34,5 \%)$ & $X^{2}=13,14$ \\
Male & $270(39,7 \%)$ & $222(32,7 \%)$ & $188(27,7 \%)$ & $\mathrm{p}=0,0014^{*}$ \\
Total & $697(39,8 \%)$ & $498(28,4 \%)$ & $558(31,8 \%)$ & \\
\hline
\end{tabular}

Frequency of eating second breakfast

\begin{tabular}{l|ccc|}
\multicolumn{1}{c|}{ Gender } & Every day & Several times a week & Don't eat \\
\hline Female & $439(39,8 \%)$ & $528(47,8 \%)$ & $137(12,4 \%)$ \\
Male & $378(51,2 \%)$ & $312(42,3 \%)$ & $48(6,5 \%)$ \\
Total & $817(44,4 \%)$ & $840(45,6 \%)$ & $185(10,0 \%)$ \\
\hline
\end{tabular}

\section{Frequency of eating dinner}

\begin{tabular}{l|ccc|c}
\multicolumn{1}{c|}{ Gender } & Every day & Several times a week & Don't eat & Statistics \\
\hline Female & $997(79,4 \%$ & $241(19,2 \%)$ & $17(1,4 \%)$ & \\
Male & $630(78,4 \%)$ & $168(20,9 \%)$ & $6(0,8 \%)$ & $\mathrm{X}^{2}=2,40$ \\
Total & $1627(79,0 \%)$ & $409(19,9 \%)$ & $23(1,1 \%)$ & $\mathrm{p}=0,3008$ \\
\hline
\end{tabular}

\begin{tabular}{|c|c|c|c|c|}
\hline \multicolumn{5}{|c|}{ Frequency of eating afternoon snack } \\
\hline Gender & Every day & Several times a week & Don't eat & Statistics \\
\hline Female & $377(34,4 \%)$ & $523(47,8 \%)$ & $195(17,8 \%)$ & \multirow{3}{*}{$\begin{array}{c}X^{2}=15,42 \\
p=0,0005^{*}\end{array}$} \\
\hline Male & $294(42,7 \%)$ & $306(44,5 \%)$ & $88(12,8 \%)$ & \\
\hline Total & $671(37,6 \%)$ & $829(46,5 \%)$ & $283(15,9 \%)$ & \\
\hline \multicolumn{5}{|c|}{ Frequency of eating supper } \\
\hline Gender & Every day & Several times a week & Don't eat & Statistics \\
\hline Female & $780(64,6 \%)$ & $333(27,6 \%)$ & $94(7,8 \%)$ & \multirow{3}{*}{$\begin{array}{l}X^{2}=133,24 \\
P<0,0001^{*}\end{array}$} \\
\hline Male & $714(87,5 \%)$ & $86(10,5 \%)$ & $16(2,0 \%)$ & \\
\hline Total & $1494(73,9 \%)$ & $419(20,7 \%)$ & $110(5,4 \%)$ & \\
\hline
\end{tabular}

Respondents who consume more meals per day are characterized by significantly higher levels of total physical activity and physical activity in sport. The total activity with 4 and more meals equates to - 3,845 MET, 3 meals - 3,419 MET, and in case of one meal - 3,620 MET. The corresponding values of sport activities are as follows: MET 1,327, 1,112 MET and 1,001 MET (Fig. 4, Tab. 5). 


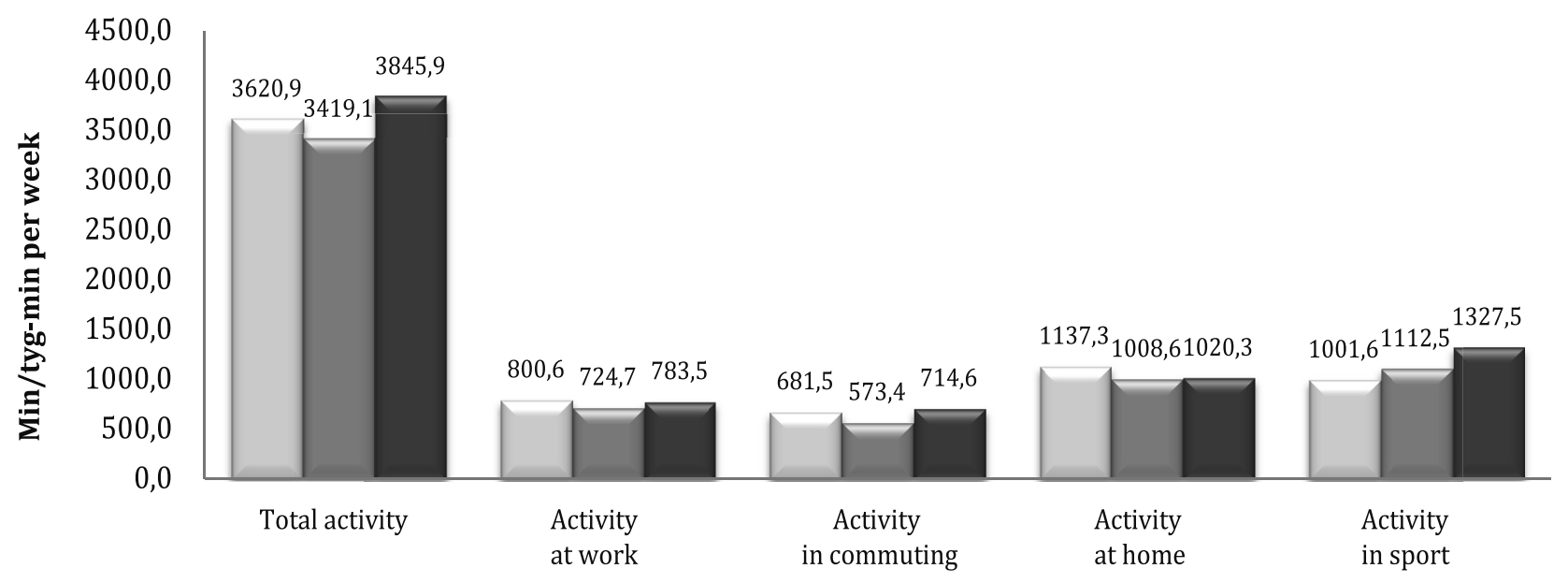

$\square 1-2 \square 3 \square 4$ and more

Figure 4. Areas of physical activity of students including number of consumed meals

Table 5. Diversification of areas of physical activity of students including number of consumed meals

\begin{tabular}{l|ccc}
\hline \multicolumn{1}{c|}{ Area of activity } & $\mathrm{H}$ & $\mathrm{p}$ & Differences \\
\hline Total activity & $\mathbf{9 , 6 2}$ & $\mathbf{0 , 0 0 8 1 *}$ & $\mathbf{2 - 3}$ ** \\
Activity at work & 3,60 & 0,1651 & - \\
Activity in commuting & 5,81 & 0,0547 & - \\
Activity at home & 4,64 & 0,0984 & - \\
Activity in sport & $\mathbf{1 3 , 4 0}$ & $\mathbf{0 , 0 0 1 2 *}$ & $\mathbf{3 - 1 , 2 * *}$ \\
\hline
\end{tabular}

*- Significant diversification at $\mathrm{p}<0,05$

**- Numbers of variables in the range of whcih there is a significant diversification at $\mathrm{p}<0,05$

Number of consumed meals: 1 - one-two, 2 - three, 3 - four and more

\section{Eating-related behaviors}

Analysis of student behaviors related to their eating habits does not reveal a clearly positive image. What is positive is undoubtedly the fact that $72,2 \%$ of respondents eat regularly,

and $27,8 \%$ do it irregularly, and that $85,2 \%$ did not experience fear of gaining weight. Less favorable information, in which it was found that $27,2 \%$ of people see the loss of control over eating, 27,4\% avoid eating and the fact that that causes vomiting 9,1\% cause vomiting out of the "care" about their figure (Tab. 6).

Table 6. Behaviors related to eating habits of the researched students

\begin{tabular}{|c|c|c|c|}
\hline \multicolumn{4}{|c|}{ Loss of control over eating } \\
\hline Gender & No & Yes & Statistics \\
\hline Females & $906(70,2 \%)$ & $385(29,8 \%)$ & \multirow{3}{*}{$\begin{array}{c}X^{2}=11,00 \\
p=0,0009^{*}\end{array}$} \\
\hline Males & $640(76,7 \%)$ & $194(23,3 \%)$ & \\
\hline Total & $1546(72,8 \%)$ & $579(27,2 \%)$ & \\
\hline \multicolumn{4}{|c|}{ Fear of putting on weight } \\
\hline Gender & No & Yes & Statistics \\
\hline Females & $1004(77,8 \%)$ & $287(22,2 \%)$ & \multirow{3}{*}{$\begin{array}{l}X^{2}=142,94 \\
p<0,0001^{*}\end{array}$} \\
\hline Males & $806(96,6 \%)$ & $28(3,4 \%)$ & \\
\hline Total & $1810(85,2 \%)$ & $315(14,8 \%)$ & \\
\hline
\end{tabular}




\begin{tabular}{|c|c|c|c|}
\hline \multicolumn{4}{|c|}{ Causing vomitting } \\
\hline Gender & No & Yes & Statistics \\
\hline Females & $1152(89,2 \%)$ & $139(70,8 \%)$ & \multirow{3}{*}{$\begin{array}{c}X^{2}=11,30 \\
p=0,0008^{*}\end{array}$} \\
\hline Males & $780(93,5 \%)$ & $54(6,5 \%)$ & \\
\hline Total & $1932(90,9 \%)$ & $193(9,1 \%)$ & \\
\hline \multicolumn{4}{|c|}{ Avoiding eating } \\
\hline Gender & No & Yes & Statistics \\
\hline Females & $833(64,5 \%)$ & $458(35,5 \%)$ & \multirow{3}{*}{$\begin{array}{l}X^{2}=108,20 \\
p<0,0001^{*}\end{array}$} \\
\hline Males & $710(85,1 \%)$ & $124(14,9 \%)$ & \\
\hline Total & $1543(72,6 \%)$ & $582(27,4 \%)$ & \\
\hline \multicolumn{4}{|c|}{ Irregular meals } \\
\hline Gender & No & Yes & Statistics \\
\hline Females & $921(71,3 \%)$ & $370(28,7 \%)$ & \multirow{3}{*}{$\begin{array}{c}X^{2}=1,31 \\
p=0,2516\end{array}$} \\
\hline Males & $614(73,6 \%)$ & $220(26,4 \%)$ & \\
\hline Total & $1535(72,2 \%)$ & $590(27,8 \%)$ & \\
\hline
\end{tabular}

*- significant diversification at $\mathrm{p}<0,05$

\section{Discussion}

The results of the study of Ukrainian youth physical activity show a positive image, as evidenced by the high value of their total physical activity-3,560 MET, which is higher than the results of other studies of students in Poland (Biernat 2011, Bergier et al. 2012, 2014, Mynarski et al. 2012).

A positive image among the surveyed students is visible in their significant participation in sports activities and active participation in training many sport disciplines.

It ought to be also emphasized that the value of their high self-assessment of physical fitness, which significantly correlates with the level of physical activity.

The characteristics of physical development, expressed within the BMI factor, it is worth to emphasize the normal body weight in the great majority of students, and the fact that almost half of young people would like to lose weight, which is a good example of healthy attitudes.

Also the characteristics of eating patterns is positive which is due to the right amount and frequency of meals. It should be emphasized that the greater amount of eaten meals is the essential factor conditioning the physical activity.

Behaviors related to nutrition are shown as less positive, as a large group indicates a loss of control over eating, avoiding food, and moreover- the fact that there is a group, though sparse, the participants of which cause vomiting for the sake of care of their figure.

Taking into account the whole scope of the results of research on physical activity, physical development and the eating habits it should be noted that students from Ukraine have a positive image of their health attitudes.

\section{Conclusions}

Detailed analysis of the researched study issue allows for some generalizations about the health-related attitudes of students from Ukraine.

1. Students have a positive ratio of total physical activity, and half of them meets the requirement of high activity.

2. Increased physical activity is characteristic of persons with sufficient amount of free time.

3. Students are fond of significant amount of sporting activity as exemplified by their active participation in many sport disciplines.

4. The physical development of most students, expressed by BMI factor, is normal with the existence of a small group of respondents with overweight problems.

5. The amount and frequency of meals reveals a positive picture of healthy behaviors and significantly determines the level of total physical activity.

6. There are certain adverse behaviors related to nutrition, such as: the loss of control over eating, avoidance of eating or an issue of causing vomiting for the sake of one's figure. 


\section{References:}

1. Andersen LB, Harro M, Sardinha LB. (2006), Physical activity and clustered cardiovascular risk in children: a cross-sectional study (The European Youth Heart Study). Lancet; 368(9532): 299-304.

2. Bergier B., Stępień E., Niźnikowska E., Bergier J. (2014), Aktywność fizyczna kobiet i mężczyzn studiujących w Państwowej Szkole Wyższej w Białej Podlaskiej. Medycyna Ogólna i Nauki o Zdrowiu. Tom 20, Nr. 2, $166-170$.

3. Bergier J., Kapka-Skrzypczak L., Biliński P., Paprzycki P., Wojtyła A. (2012), Physical activity of Polish adolescents and young adults according to IPAQ: a population based study. Ann Agric Environ Med.; 19(1): 109-115. 779.

4. Biernat E. (2011), Aktywność fizyczna mieszkańców Warszawy. Na przykładzie wybranych grup zawodowych. Szkoła Główna Handlowa.

5. Blair S.N., Brodney S. (1999), Ects of physical inactivity and obesity on morbidity and mortality: current evidence and research issues. Med. Sci Sports Exerc; 31: 646-62.

6. Blair S., Cheng Y., Holder J. (2001), Is physical activity or physical fitness more import ant in defining health benefits? Med Sci Sport Exerc.; 33: 379-399.

7. Krejpcio Z., Staniek H., Chmielewska A. (2013), Ocena powszechności spożycia suplementów diety w wybranych grupach studentów. Probl Hig Epidemiol; 94 (3): 622-625.

8. Marzec Z., Koch W. (2013), Ocena pobrania wybranych składników odżywczych z całodziennymi racjami pokarmowymi studentów. Probl Hig Epidemiol; 93 (3): 619-621.

9. Mynarski W., Rozpara M., Królikowska B., Puciato D., Graczykowska B. (2012), Jakościowe i ilościowe aspekty aktywności fizycznej. Oficyna Wydawnicza Politechniki Opolskiej, Opole.

10. Myszkowska-Ryciak J., Kraśniewska A., Harton A., Gajewska D. (2011), Porównanie wybranych zachowań żywieniowych studentek Akademii Wychowania Fizycznego i Szkoły Głównej Gospodarstwa Wiejskiego w Warszawie. Probl Hig Epidemiol; 91 (4): 931-934.

11. Rębacz-Maron E., Pawlak M., Michnik K. (2013), Stan odżywienia i aktywność fizyczna wśród studentek Uniwersytetu Szczecińskiego. Hygeia Public Health; 94 (2): 371-377.

12. Romanowska-Tołłoczko A. (2011), Styl życia studentów oceniany w kontekście zachowań zdrowotnych. Hygeia Public Health; 46 (1): 89-93.

13. Rywik S., Pająk A., Broda G (2003), Częstość występowania nadwagi i otyłości w wybranych populacjach Polski - POL-MONIKA BIS projekt. Med Matabol; 2, 8-15.

14. Seń M., Zacharczuk A., Lintowska A. (2012), Zachowania żywieniowe studentów wybranych uczelni wrocławskich a wiedza na temat skutków zdrowotnych nieprawidłowego żywienia. Piel Zdr Publ; 2,2: 113-123.

15. Szczodrowska A., Krysiak W. (2013), Analiza wybranych zwyczajów żywieniowych oraz aktywności fizycznej studentów łódzkich szkół wyższych. Probl Hig Epidemiol; 94 (3): 518-521.

16. Szponar L., Sekuła W., Rychlik E., Ołtarzewski M., Figurska K. (2003), Badania indywidualnego spożycia żywności i stanu odżywiania w gospodarstwach domowych. Instytut Żywności i Żywienia, Warszawa.

17. Zdrojewski T., Bandosz P., Szpakowski P. (2004), Rozpowszechnienie głównych czynników ryzyka chorób układu sercowo-naczyniowego w Polsce. Wyniki badań NATPOL PLUS. Kardiol Pol; 61, (suppl. 4), 1-26.

Submitted: 09.11.2014

Accepted: 04.12.2014 